\title{
Perancangan Sistem Informasi Point Of Sales Berbasis Web Pada Perusahaan Sablon
}

\author{
Fitra Adhitya Sandi ${ }^{1}$, Laila Septiana ${ }^{2}$ \\ 1,2Program Studi Sistem Informasi, Fakultas Teknologi Informasi, Universitas Nusa Mandiri \\ J1. Raya Jatiwaringin, Cipinang Melayu, Makasar, Jakarta Timur-13630, Indonesia \\ e-mail: ${ }^{1}$ fitraadhityas@gmail.com, ${ }^{2}$ laila@ nusamandiri.ac.id
}

Artikel Info : Diterima : 28-02-2021 | Direvisi : 18-06-2021 | Disetujui : 19-07-2021

\begin{abstract}
Abstrak - Sistem penjualan yang berjalan pada CV. Wadas Warna Warni (Dyotees) saat ini masih dilakukan secara konvensional, menurut pengamatan penulis, hal tersebut sangat tidak efektif, dimana Customer Service harus membuat form order secara konvensional menggunakan Microsoft Excel yang berisi detail penjualan dan perhitungan penjualan, kemudian mencetak form order dan juga mendisposisikan form order tersebut kepada bagian produksi, pembuatan dan perhitungan invoice yang masih dilakukan secara konvensional menggunakan Microsoft Excel. Hal ini menyebabkan sering terjadinya kesalahan input, redudansi data dan juga membutuhkan waktu yang lama untuk mendisposisikan pesanan kepada bagian produksi, sulitnya memonitor penjualan yang sedang diproses ataupun sudah selesai diproses produksi serta membutuhkan waktu yang lama dalam proses perhitungan laporan laba rugi untuk bagian accounting dimana bagian accounting harus merekap seluruh data invoice. Dengan merancang sistem Informasi Point Of Sales (POS) ini diharapkan dapat mempermudah proses penjualan dimana pembuatan dan perhitungan form order secara otomatis, pembuatan laporan dan juga pengelolaan data penjualan yang lebih terorganisir.
\end{abstract}

Kata Kunci : Point Of Sales, Penjualan, Perancangan Web

Abstracts - The sales system that runs on CV. Wadas Warna Warni (Dyotees) is currently still done conventionally, according to the author's observation, it is very ineffective, where Customer Service has to make a conventional order form using Microsoft Excel which contains details of sales and sales calculations, then prints the order form and also disposes the order form. to the production, invoice creation and calculation which is still done conventionally using Microsoft Excel. This causes frequent input errors, data redundancies and also takes a long time to position orders to the production department, it is difficult to monitor sales that are being processed or have finished processing production and requires a long time in the process of calculating the income statement for the accounting department where the division is accounting must recap all invoice data. By designing the Point of sales (POS) Information system, it is hoped that it can simplify the sales process in which the creation and calculation of order forms automatically, report generation and also management of more organized sales data.

Keywords : Point of sales (POS), Sales, Web Design

\section{PENDAHULUAN}

Sablon adalah sebuah teknik mencetak tinta diatas bahan dengan bentuk yang kita kehendaki. Dengan bantuan screen sablon dan rakel sablon dalam proses pengerjaannya. Saat ini usaha penjualan produk sablon sudah cukup tinggi, seiring meningkatnya kebutuhan masyarakat akan pakaian dan juga meningkatnya tren saat ini menjadikan usaha di bidang ini sebuah peluang usaha yang menjanjikan.

CV. Wadas Warna Warni (Dyotees) merupakan salah satu perusahaan yang bergerak dalam bidang jasa sablon di daerah condet Jakarta timur yang melayani jasa pembuatan dan penyablonan sesuai dengan permintaan konsumen. Rata-rata perusahaan memproduksi sekitar dua ratus sampai dengan empat ratus potong produk per hari. Jumlah tersebut tentunya akan terus meningkat seiring kebutuhan dan perkembangan perusahaan.

Saat ini proses bisnis yang terjadi pada perusahaan masih menggunakan metode konvensional dimana terdapat berbagai permasalahan, yaitu pembuatan form order yang dilakukan secara konvensional oleh customer service, disposisi ke bagian produksi menggunakan cetakan konvensional, sulitnya pencarian data, kurang terpantaunya status order dan pembuatan laporan penjualan yang masih dilakukan secara konvensional. 
Sistem secara konvensional membuat proses bisnis menjadi tidak efektif, oleh karena itu perusahaan harus memiliki sistem infornasi yang akan membuat proses bisnis menjadi lebih efektif dan mengurangi kesalahan informasi dalam pencatatan penjualan dan pembuatan laporan penjualan perusahaan.(Marisa \& Yuarita, 2017)

Sistem informasi adalah sebuah system yang terdiri dari rangkaian subsistem informasi terhadap pengolahan daya untuk menghasilkan informasi yang berguna dalam pengambilan keputusan.(Nuryamin \& Saraswati, 2018). Point of sales (POS) merupakan skema dalam menyelesaikan transaksi penjualan. Pada Point of sales $(P O S)$ penjual akan melakukan perhitungan jumlah yang harus dibayar oleh pelanggan, menunjukkan jumlah itu, dapat menyiapkan faktur untuk pelanggan dan menunjukkan opsi bagi pelanggan untuk melakukan pembayaran..(Lavenia et al., 2019). Sistem informasi pada distributor toko Aneka Utama Desa Balerejo Madiun membantu mengatasi permasalahan data yang tidak bisa diakses secara Bersama-sama dan nota penjualan yang masih dilakukan secara konvensional.(Sibli, 2020). Gudang Kopi Oncak memerlukan sebuah sistem informasi untuk membantu permasalahan pencatatan data pelanggan, pencatatan data karyawan dan pencatatan laporan transaksi yang masih dilakukan secara kovensional.(Santgani \& Angellia, 2020). Sistem Informasi pada CV. Satria Hendra Jaya Pekanbaru mengatasi permasalahan dimana pemrosesan data transksi masih menggunakan media kertas, admin juga mengalami kesulitan dan membutuhkan waktu yang lama dalam memproses pembuatan laporan transaksi penjualan.(Irawan et al., 2019). PT. Mustika Jati memerlukan sistem informasi untuk membantu mengatasi permasalahan dalam pembuatan laporan penjualan yang membutuhkan waktu lama, adanya redudansi data dan manipulasi data pada data transaksi penjualan.(F. Ramadhan \& Purwandari, 2018). Pembuatan sistem informasi point of sales (POS) pada pasar swalayan di daerah karawang mempermudah transaksi penjualan dan dapat menghindari terjadinya kesalahan data pada transaksi penjualan.(M. G. Ramadhan et al., 2020). Dalam perancangan sistem informasi ini menggunakan pendekatan metode waterfall, desain pengembangan UML dan Bahasa pemrograman PHP dan database Mysql.(Cahyodi \& Arifin, 2017). Pada perancangan sistem informasi di pasar swalayan daerah karawang menggunakan metode waterfall menghasilkan sebuah sistem informasi point of sales (POS) yang menghasilkan respon positif terhadap sistem tersebut dimana sebesar 57\% setuju bahwa sistem tersebut user friendly, mudah dioperasikan dan membantu transaksi penjualan menjadi lebih efektif dan efisien.(M. G. Ramadhan et al., 2020)

Berdasarkan permasalahan tersebut, CV. Wadas Warna Warni (Dyotees) perlu melakukan perubahan terhadap proses penjualan dengan menggunakan sistem informasi point of sales (POS) berbasis web untuk mengatasi permasalahan yang terjadi dan membantu perusahaan agar proses penjualan menjadi lebih ekfektif dan akurat.

\section{METODE PENELITIAN}

Metode penelitian yang digunakan oleh penulis disini adalah metode waterfall. Model waterfall atau air terjun meneyediakan pendekatan alur hidup perangkat lunak secara sekuensial atau terurut dimulai dari analisis, desain, pengkodean, pengujian dan tahap pendukung (support).(Rusdi et al., 2019)

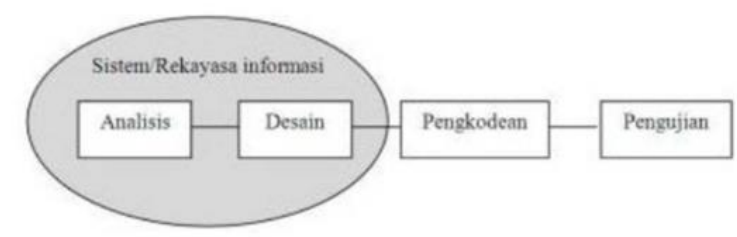

Sumber : (Rusdi et al., 2019)

Gambar 1. Illustrasi Model Waterfall

Dengan tahapan-tahapan sebagai berikut:

1. Analisa Kebutuhan

Analisa kebutuhan dibagi menjadi dua yaitu kebutuhan fungsional dan kebutuhan non fungsional. Analisa kebutuhan fungsional adalah kebutuhan sistem untuk mengolah data penjualan CV. Wadas Warna Warni (Dyotees) dengan 4 hak akses, yaitu customer service, produksi, accounting dan owner. Adapun kebutuhan non fungsional dibagi menjadi dua, yaitu perangkat lunak (software) dan perangkat keras (hardware). Untuk perangkat keras yang digunakan meliputi prosesor Pentium Core, ram 1GB, sedangkan perangkat lunak yang digunakan meliputi sistem operasi window 10, browser chrome, dreamwaver dan juga xampp server.

2. Desain

Pada tahap ini penulis melakukan perancangan program dalam bentuk Unified Modelling Language $(U M L)$, Entity Relationship Diagram (ERD) dan juga Logical Record Structure (LRS) dalam 
perancangan database.

3. Pengkodean

Berdasarkan hasil desain program yang dibuat, penulis merancang pemrograman menggunakan bahasa pemrograman PHP, HTML, Framework Bootstrap dan database Mysql.

4. Pengujian

Pada tahap ini penulis melakukan pengujian pada sistem yang sudah dibuat menggunakan blackbox testing untuk mengetahui apakah sistem yang dibuat sudah berjalan sesuai dengan yang diharapkan dan juga untuk mengetahui kekurangan pada sistem sebelum dioperasikan.

5. Support Menyediakan apa saja yang dibutuhkan untuk mendukung agar sistem dapat berjalan dengan baik dan mengantisipasi hal-hal yang tidak terduga, baik dalam hal software maupun hardware.

Dalam proses pengumpulan data, penulis melakukan dalam beberapa tahap, yaitu

1. Metode observasi merupakan cara pengumpulan data secara langsung dengan mengamati onjek penelitian di CV. Wadas Warna Warni (Dyotees). Adapun proses yang diamati adalah proses pembuatan form order dan invoice, proses disposisi order ke bagian produksi dan juga pembuatan laporan penjualan.

2. Wawancara

Pada metode ini penulis melakukan sesi tanya jawab secara langsung dengan objek penelitian, yaitu melakukan wawancara dengan owner dan beberapa karyawan yang ada di CV. Wadas Warna Warni (Dyotees).

3. Studi Pustaka

Penulisan penelitian ini ditunjang oleh beberapa jurnal, buku-buku yang berisi tentang teori-teori yang berkaitan dengan masalah yang dibahas serta penunjang lainnya.

\section{HASIL DAN PEMBAHASAN}

1. Tahapan Analisis

Sistem informasi point of sales (POS) pada CV. Wadas Warna Warni (Dyotees) membutuhkan user dengan peran sebagai customer service yang dapat melakukan proses penjualan, mengelola data penjualan dan menginput data pembayaran. User dengan peran sebagai produksi yang dapat memproses data produksi penjualan, user dengan peran sebagai accounting yang dapat membuat laporan penjualan dan laporan detail penjualan dan juga user owner yang dapat mengelola data produk dan juga melihat laporan penjualan.

2. Desain

Pada tahapan desain, penulis merancang sistem usulan dengan menggunakan diagram Unified Model Language (UML), sedangkan untuk rancangan database, penulis menggunakan Entity Relationship Diagram (ERD) dan Logical Record Structure (LRS), serta penggunaan framework bootstrap untuk membuat tampilan user interface.

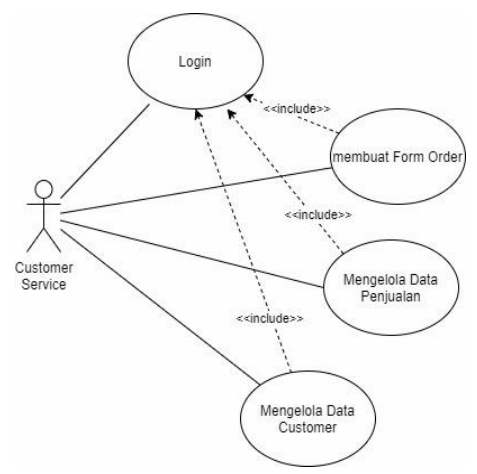

Gambar 2. Use Case Diagram Point of sales (POS) Customer Service

Pada gambar 2 menunjukkan dimana user customer service dapat melakukan proses pembuatan form order, megelola data penjualan dan juga untuk mengelola data customer, dimana user diharapkan untuk melakukan proses login terlebih dahulu. 
Computer Science (CO-SCIENCE)

Volume 1 No. 2 Juli 2021 | E-ISSN: 2774-9711

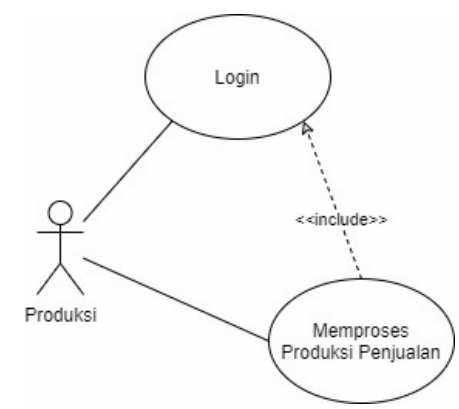

Gambar 3. Use Case Diagram Point of sales (POS) Produksi

Pada gambar 3 menunjukkan dimana user produksi dapat memproses data produksi penjualan, dimana $u s e r$ produksi diharapkan untuk melakukan proses login terlebih dahulu.

Berikut adalah gambar Activity Diagram pembuatan form order sistem informasi point of sales (POS) CV. Wadas Warna Warni (Dyotees) pada user customer service.

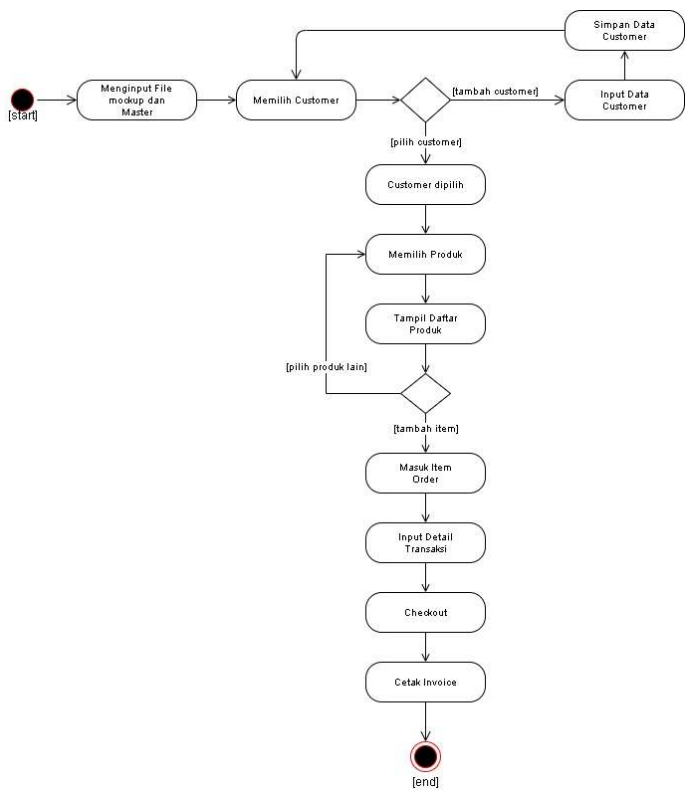

Gambar 4. Activity Diagram Point of sales (POS) Pembuatan Form Order

Pada gambar 4 menggambarkan kegiatan user customer service saat melakukan proses pembuatan form order dimana user customer service dapat mengupload file desain, menginput produk dan menginput jumlah produk yang dipesan customer. 
Computer Science (CO-SCIENCE)

Volume 1 No. 2 Juli 2021 |E-ISSN: 2774-9711

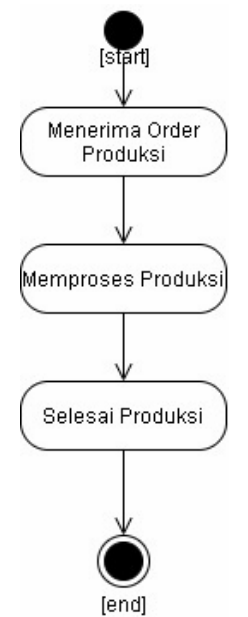

Gambar 5. Activity Diagram Point of sales (POS) Produksi Penjualan

Pada gambar 5 menunjukkan bahwa pada halaman ini user produksi dapat memproses produksi penjualan yang sebelumnya telah dibuat oleh customer service pada proses pembuatan form order.

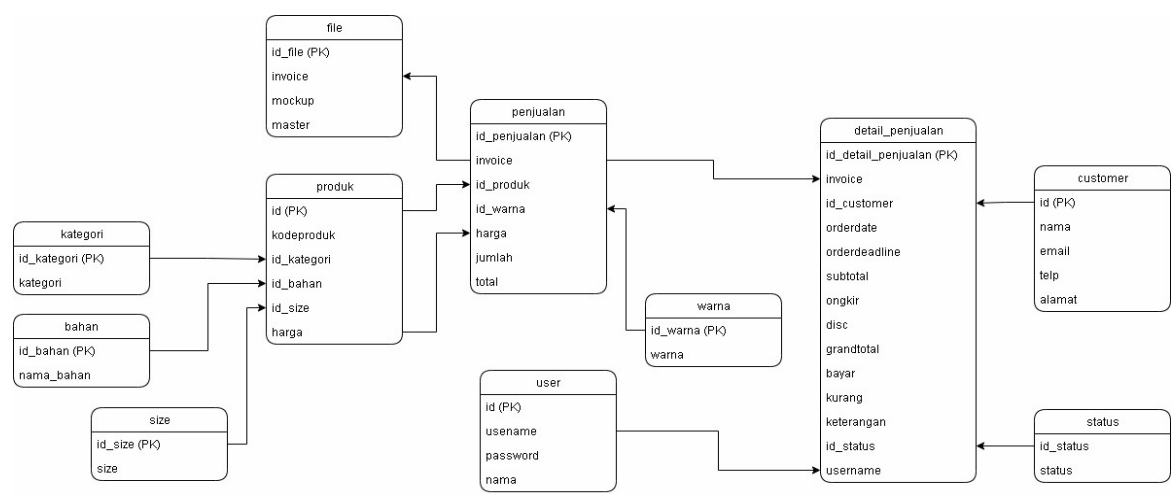

Gambar 6. Logical Record Structure (LRS) Point of sales (POS)

Gambar 6 menunjukkan Logical Record Structure (LRS) database yang digunakan oleh sistem informasi point of sales (POS) CV.Wadas Warna Warni (Dyotees), yang terdiri dari 11 (sebelas) tabel yang saling berelasi yaitu tabel kategori yang berfungsi menyimpan data kategori, tabel bahan yang berfungsi menyimpan data bahan, tabel size yang berfungsi menyimpan data size, tabel file yang berfungsi menyimpan data file, tabel produk yang berfungsi menyimpan data produk, tabel penjualan yang berfungsi menyimpan data penjualan, table warna yang berfungsi menyimpan data warna, table detail_penjualan yang berfungsi menyimpan data detail_penjualan, table customer yang berfungsi menyimpan data customer, table status yang berisi data status dan juga table user yang berisi data user yang dapat masuk ke sistem informasi point of sales (POS) CV.Wadas Warna Warni (Dyotees).

3. User Interface Halaman Customer Service

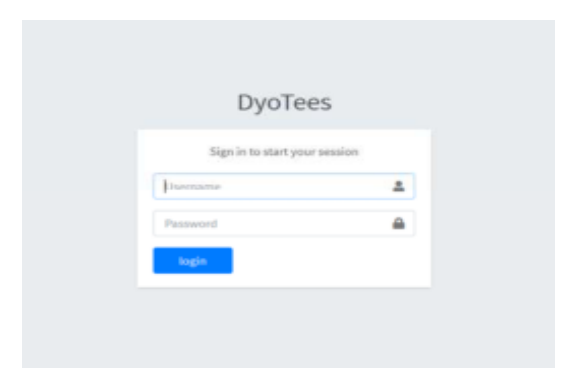

Gambar 7. Tampilan Halaman Login 
Pada gambar 7 menunjukkan halaman login untuk semua user pada sistem informasi point of sales (POS) CV. Wadas Warna Warni (Dyotees) dimana seluruh user diharapkan untuk melakukan proses login terlebih dahulu.

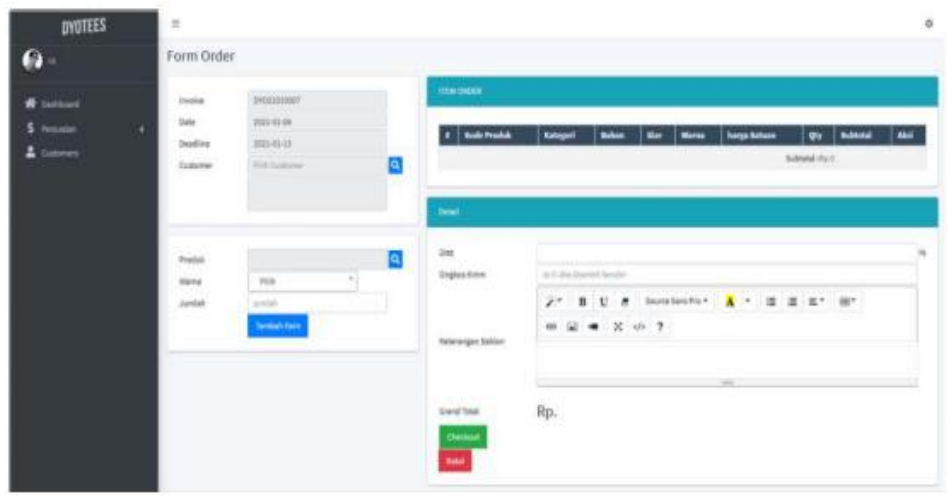

Gambar 8. Tampilan Halamn Pembuatan form order

Pada gambar 8 menunjukkan halaman pembuatan form order dimana customer service menginput file, memilih customer, memilih produk dan jumlah produk yang dipesan oleh customer

4. User Interface Halaman Produksi

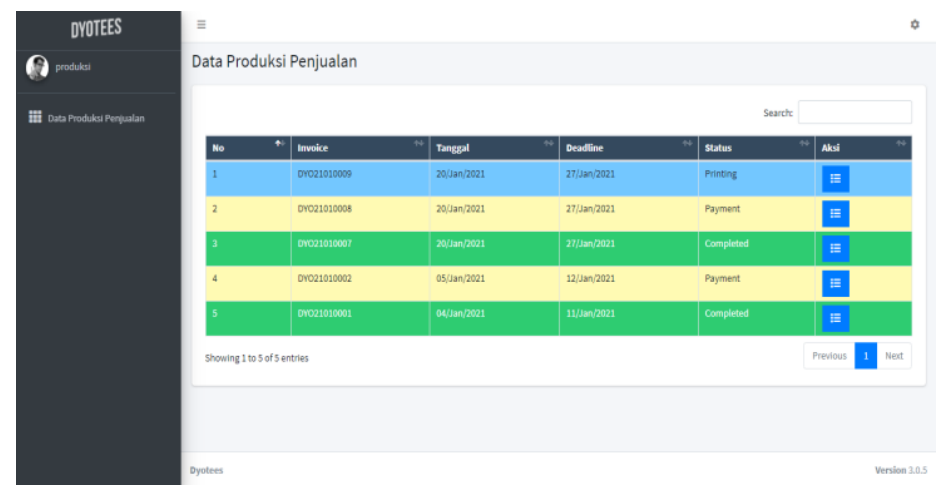

Gambar 9. Tampilan Halaman Produksi Untuk Memproses Data Produksi Penjualan

Pada halaman ini, user produksi diharapkan melakukan login terlebih dahulu dan kemudian user produksi dapat memproses data produksi penjualan dan merubah status menjadi printing jika sedang dalam proses produksi dan merubah status menjadi printed jika proses produksi telah selesai.

5. Pengujian

Berikut merupakan daftar pengujian sistem informasi point of sales (POS) pada CV. Wadas Warna Warni (Dyotees) dengan menggunakan blackbox testing. 
Tabel 1. Blackbox testing transaksi checkout

\begin{tabular}{cll}
\hline No & Skenario & Test Case \\
1 & $\begin{array}{l}\text { Tidak Memilih file } \\
\text { mockup tidak memilih } \\
\text { file master lalu klik upload }\end{array}$ & $\begin{array}{l}\text { file mockup dan file } \\
\text { master tidak dipilih }\end{array}$ \\
\hline 2 & $\begin{array}{l}\text { Memilih file mockup dan } \\
\text { tidak memilih file master }\end{array}$ & $\begin{array}{l}\text { file mockup dipilih } \\
\text { dan file master tidak } \\
\text { dipilih }\end{array}$ \\
3 & $\begin{array}{l}\text { tidak memilih file mockup } \\
\text { dan memilih file master }\end{array}$ & $\begin{array}{l}\text { file mockup tidak } \\
\text { dipilih dan file master } \\
\text { dipilih }\end{array}$ \\
& &
\end{tabular}

4 Memilih file mockup dan memilih file master lalu klik upload

5 customer tidak dipilih, produk dipilih, warna dipilih, jumlah diisi lalu klik "tambah item"

6 customer dipilih, produk tidak dipilih, warna dipilih dan jumlah diisi lalu klik "tambah item"

$7 \quad$ customer dipilih, produk dipilih, warna tidak dipilih, jumlah diisi lalu klik "tambah item"

8 customer dipilih, produk dipilih, warna dipilih, jumlah tidak diisi lalu klik "tambah item"

9 customer diipilih, produk dipilih, warna dipilih, dan jumlah disii lalu klik "tambah item"

10 disc tidak diisi, ongkos kirim diisi, keterangan diisi lalu klik checkout

11 disc diisi, ongkos kirim tidak diisi, keterangan diisi lalu klik checkout file mockup dan file master dipilih

customer tidak dipilih, produk dipilih, warna dipilih dan jumlah diisi

customer dipilih, produk tidak dipilih, warna dipilih dan jumlah diisi

customer dipilih, produk dipilih, warna tidak dipilih dan jumlah diisi

customer dipilih, produk dipilih, warna dipilih dan jumlah tidak diisi

customer dipilih, produk dipilih, warna dipilih dan jumlah diisi

disc tidak diisi, ongkos kirim diisi dan keterangan diisi

disc diisi, ongkos keterangan diisi kirim tidak diisi dan
Hasil yang Diharapkan

Sistem menolak upload dan menampilkan pesan "Pilih File"

sistem menolak upload dan
menampilkan pesan "pilih
file" pada kolom input file
master
sistem menolak upload dan
menampilkan pesan "pilih
file" pada kolom input file
mockup

sistem berhasil mengupload file dan menampilkan halaman form order

sistem menolak menambah item ke item order, dan menampilkan pesan "harap isi bidang ini" pada kolom customer

sistem menolak menambah item ke item order, dan menampilkan pesan "harap isi bidang ini" pada kolom produk

sistem menolak menambah item ke item order, dan menampilkan pesan "Pilih item pada daftar" pada kolom warna

sistem menolak menambah item ke item order, dan menampilkan pesan "Harap isi bidang ini" pada kolom jumlah

sistem akan menambahkan item ke item order

Sistem akan menolak checkout dan menampilkan pesan "harap isi bidang ini" pada kolom disc

sistem akan menolak checkout dan menampilkan pesan "harap isi bidang ini" pada kolom ongkos kirim
Has pengujian

Sesuai

Harapan

Sesuai

harpaan

Valid

.

Sesuai

Valid

Harapan

Sesuai

Valid harapan

Sesuai

Valid

Harapan

Sesuai

Valid

harapan

Sesuai

Valid

Harapan

Sesuai

Valid

Harapan

Sesuai

Valid

Harapan

Sesuai

Valid

Harapan

Sesuai

Valid 
12 disc diisi, ongkos kirim diisi, keterangan tidak diisi lalu klik checkout

13 disc diisi, ongkos kirim diisi, keterangan diisi lalu klik checkout

\begin{abstract}
disc diisi, ongkos
kirim diisi, dan

keterangan tidak diisi
\end{abstract}

disc diisi, ongkos

kirim diisi dan

keterangan diisi sistem akan menolak

Sesuai Valid checkout dan menampilkan pesan "harap isi bidang ini" pada kolom keterangan

sistem akan menerima checkout dan menampilkan halman invoice
Harapan

Sesuai Valid harapan

\section{KESIMPULAN}

Dengan dibuatnya sistem informasi point of sales (POS) ini, proses bisnis pada CV. Wadas Warna Warni (Dyotees) menjadi lebih efisien dan lebih efektif tanpa adanya proses pembuatan dokumen-dokumen secara konvensional, kemudahan dalam pencarian data dan juga proses disposisi kepada bagian produksi. Sistem ini juga dapat mengurangi terjadinya human error dan redudansi data yang menghambat kelancaran proses bisnis pada CV. Wadas Warna Warni (Dyotees).

Selanjutnya perlu adanya penelitian lebih lanjut untuk pengujian kualitas dan penerimaan sistem informasi point of sales (POS) ini kepada pengguna sebagai informasi dan masukan sebagai pengembangan sistem selanjutnya.

\section{REFERENSI}

Cahyodi, S. C., \& Arifin, R. W. (2017). Sistem Informasi Point Of Sales Berbasis Web Pada Colony Amaranta Bekasi. INFORMATION SYSTEM FOR EDUCATORS AND PROFESSIONALS, 1(2), 189-204.

Irawan, Y., Rahmalisa, U., Wahyuni, R., \& Devis, Y. (2019). Sistem Informasi Penjualan Furniture Pada CV. Satria Hendra Jaya Pekanbaru Berbasis Web. JTIM : Jurnal Teknologi Informasi Dan Multimedia, 1(2), 150-159. https://doi.org/10.35746/jtim.v1i2.4

Lavenia, B. H., Hayuhardhika, W., Putra, N., \& Hanggara, B. T. (2019). Pengembangan Sistem Informasi Point of Sales untuk Bengkel berbasis Cloud Computing ( Studi Kasus : Bengkel Mas Pur Baturaja ). Jurnal Pengembangan Teknologi Informasi Dan Ilmu Komputer, 3(10), 9444-9449.

Marisa, F., \& Yuarita, T. G. (2017). Perancangan Aplikasi Point of Sales (Pos) Berbasis Web Menggunakan Metode Siklus Hidup Pengembangan Sistem. Jurnal Teknologi Dan Manajemen Informatika, 3(2), 167171. https://doi.org/10.26905/jtmi.v3i2.1514

Nuryamin, Y., \& Saraswati, S. D. (2018). Rancang Bangun Sistem Informasi Penjualan Buket Bunga Kain Flanel Florist Menggunakan Metode Waterfall. JURIKOM (Jurnal Riset Komputer), 5(5), 449-453.

Ramadhan, F., \& Purwandari, N. (2018). Sistem Informasi Penjualan Berbasis Web pada PT. Mustika Jati. KALBI $\begin{array}{lllll}\text { Scientia Jurnal Sains } & \text { Tan-57. }\end{array}$ http://research.kalbis.ac.id/Research/Files/Article/Full/ET722JFJEKQYRF2PKZC1UBQOU.pdf

Ramadhan, M. G., Nurpulaela, L., \& Latifa, U. (2020). Perancangan Sistem Informasi Pos (Point of Sales) Berbasis Web Dengan Menggunakan Framework Codeigniter Pada Pasar Swalayan. Electrician, 14(3), 76-83. https://doi.org/10.23960/elc.v14n3.2155

Rusdi, I., Widy, I. F., \& Peratiwi, N. (2019). Rancang Bangun Sistem Informasi Manajemen Skripsi Berbasis Web menggunakan Model Waterfall. 2(1).

Santgani, B. N., \& Angellia, F. (2020). Analisis Sistem Penjualan Dengan Point of Sales ( POS ) Berbasis Web Di Gudang Kopi Oncak. JUNSIBI, 1(1), 12-20.

Sibli, M. (2020). IMPLEMENTASI SISTEM INFORMASI PENJUALAN DAN PEMBELIAN BERBASIS WEBSITE PADA DISTRIBUTOR TOKO ANEKA UTAMA DESA BALEREJO MADIUN. Seminar Nasional Teknologi Informasi Dan Komunikasi “Inovasi Disruptif Teknologi Informasi Di Era Normal Baru," 170. 